\title{
CONJUCTURE EFFECT OF OPERATIONAL COST FOR INCREASING FINANCIAL PERFORMANCE PT. GOTONG ROYONG JAYA
}

\author{
${ }^{1 *}$ Irada Sinta, ${ }^{2}$ Emmia Tambarta Kembaren, ${ }^{3}$ Fadli \\ ${ }^{123}$ Faculty of Agriculture Universitas Malikussaleh \\ *Corresponding Author: irada@unimal.ac.id
}

\begin{abstract}
ABSTRACK
This study aims to determine how the Effect of Operational Costs on the Financial Performance of PT. Gotong Royong Jaya. The research method used is quantitative data method. While the data used is secondary data. The data analysis method in this study uses simple linear regression analysis to obtain a comprehensive picture of the effect of the variable Operating Costs on Financial Performance by using the SPSS 25 for Windows program. To find out whether there is a significant effect of the independent variable on the dependent variable, a simple linear regression model is used. The results of hypothesis testing using simple regression analysis and t-test indicate that: the t-table value of the Operating Cost variable is $6.862>$ the t-table value (df: : $35 \%$ ) is 2.030 so it can be concluded that the Operational Cost has a positive and significant effect on the Financial Performance of PT. Gotong Royong Jaya.
\end{abstract}

Key Words : Operating Costs, Financial Performance.

\section{PRELIMINARY}

Financial performance is an analysis carried out to see the extent to which a company has implemented it using financial implementation rules properly and correctly (Fahmi 2014:2). Such as by making a financial report that meets the standards and provisions in SAK (Indonesian Accounting Standards) or GAAP (General Accepted Accounting Principles) and others. Financial ratios are activities to compare the numbers in the financial statements by dividing one number by another. Comparisons can be made between one component with other components in one financial report or between components that exist between financial statements (Kasmir, 2016: 104).

Companies in the current era of globalization are required to be able to adapt to an environment with relatively fast changes that are uncontrollable and face increasingly competitive competition. So that in order to win the competition in business competition, the company must have a competitive advantage. Competitive advantage is when a company can do something that a rival company cannot or has something that a rival company wants, then it can represent a competitive advantage (David, 2011).

PT. Gotong royong jaya is a company engaged in the plantation sector which in recent years has experienced a decline in financial performance in the form of a decrease in company profits. Based on an internal survey conducted by looking at the results of the audit of the company's financial statements, it can be seen that operating expenses have increased quite significantly in the last two years, thus affecting the company's income level which has 


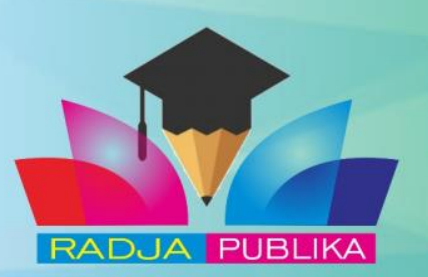

Volume 1 No. 1 (2021)

International Journal of Economic, Business,

Accounting, Acriculture Management and Sharia Administation

decreased. This happens because there are several components of operational costs that cannot be controlled by the amount of output.

Such planning and supervision must be carefully prepared, with full consideration and adapted to the conditions and developments of the company itself. Every company must have planning and supervision that can streamline and streamline their respective operational activities. Planning is an important function among all functions. One of the important aspects of planning is decision making, the process of developing and selecting a set of activities to solve a particular problem.

PT. Gotong royong jaya can run the company's operations must incur costs. Cost is an important element in carrying out the operating activities of a company, because costs must first be incurred before producing a product, either in the form of goods or services. Cost is an economic sacrifice, measured in units of money, that has occurred or is likely to occur to achieve organizational goals, including the cost of goods sacrificed in an effort to earn income.

Based on the results of observations made by the author in the finance department at the PT. Gotong royong jaya company which is engaged in oil palm plantations, it turns out that there have been several irregularities in the company's operational cash flow statements which have caused operational costs to increase, so the impact has been a decrease in company income.

\section{LITERATURE REVIEW}

\subsection{Operational Cost Monitoring Analysis}

Understanding Costs According to Mulyadi (2014) states that the definition of costs is as follows: "Costs are sacrifices of economic resources, which are measured in units of money that have become or are likely to occur for certain purposes". According to Mursyidi (2010), the definition of cost is as follows: "Cost is defined as a sacrifice that can reduce cash or other assets to achieve goals that can be charged both now and in the future". Meanwhile, according to Sofyan Syafri Harahap (2011) states that the definition of cost is as follows: "Costs are all that is charged to goods and services products that will be sold to get revenue".

\subsection{Performance Control}

Control and Performance Control is the process of directing a set of variables that include people, objects, situations, and organizations to achieve predetermined goals or objectives. Meanwhile, performance is a display of the complete state of the company during a certain period of time, is the result or achievement that is influenced by the company's operational activities in utilizing the resources owned. The interaction between the character of the organization and human behavior will affect the design and use of the control system.

\subsection{Company Performance Measurement with Financial Approach}

According to Kasmir (2012, p. 196) Assessment of the company's condition on management's efforts in carrying out its functions within a certain period is financial performance and media financial reports are used in assessing financial performance so that financial statements are the final result of the accounting process that shows the current 
condition of the company. This is a medium of communication between financial data and company activities for interested parties for decision making in a certain period.

\subsection{Company Performance Measurement with Balanced Scorecard Approach}

Understanding the Balanced Scorecard The rapid development of information technology has changed the pattern of company competition from industrial competition to information competition, which has changed the reference used to measure the performance of a company. Traditional performance measurement tools that focus on financial measurement must of course shift according to the demands in order to provide a better direction for the company. Only by using financial measures alone, can not describe the performance of a company as a whole.

\section{RESEARCH METHODS}

\subsection{Population and Sample}

\subsubsection{Population}

The definition of population according to Sugiyono (2011: 115) is a generalization area consisting of objects or subjects that have certain qualities and characteristics determined by researchers to be studied and then drawn conclusions. In this study, the population is monthly data from survey data, monthly reports on operating costs and company performance measurements from January 2016 to December 2018 totaling 36 monthly reports.

\subsubsection{Sample}

Sugiyono (2011:64) suggests that the sample is part of the number and characteristics possessed by the population. In this study, researchers faced a case where the population was very large, so the researcher chose the sampling method to be used was the census method, namely 36 Monthly Report data on operating costs and company performance measurements from January 2016 to December 2018 obtained from source of the company's cash flow statement.

\subsubsection{Variable Operational Definition}

\begin{tabular}{|c|c|c|c|c|}
\hline No & Variable & Definition & Measurement Method & Scale \\
\hline 1 & $\begin{array}{l}\text { Operating } \\
\text { costs } \\
(\mathrm{X})\end{array}$ & $\begin{array}{l}\text { Murhadi } \text { (2013) } \\
\text { "Operating expenses are } \\
\text { costs related to company } \\
\text { operations which include } \\
\text { selling and administrative } \\
\text { expenses, advertising } \\
\text { expenses, depreciation and } \\
\text { amortization expenses, as } \\
\text { well as repairs and } \\
\text { maintenance (repairs and } \\
\text { maintenance expense)". }\end{array}$ & $\begin{array}{l}\text { Murhadi (2013) CFOt/At-1 } \\
=(1 / \text { At-1 })+1 \text { St } / \text { At- } 1+2 \\
\text { St-1/ At- } 1+\mathrm{e} \\
\text { Information: } \\
\text { CFOt/At-1 = Cash flow } \\
\text { from operating activities in } \\
\text { year t scaled } \\
\text { with total assets in year t-1. } \\
\text { (1/At-1) = Intercept scaled } \\
\text { by total assets in year t-1 } \\
\text { with the aim that operating } \\
\text { cash flow does not have a }\end{array}$ & Ratio \\
\hline
\end{tabular}




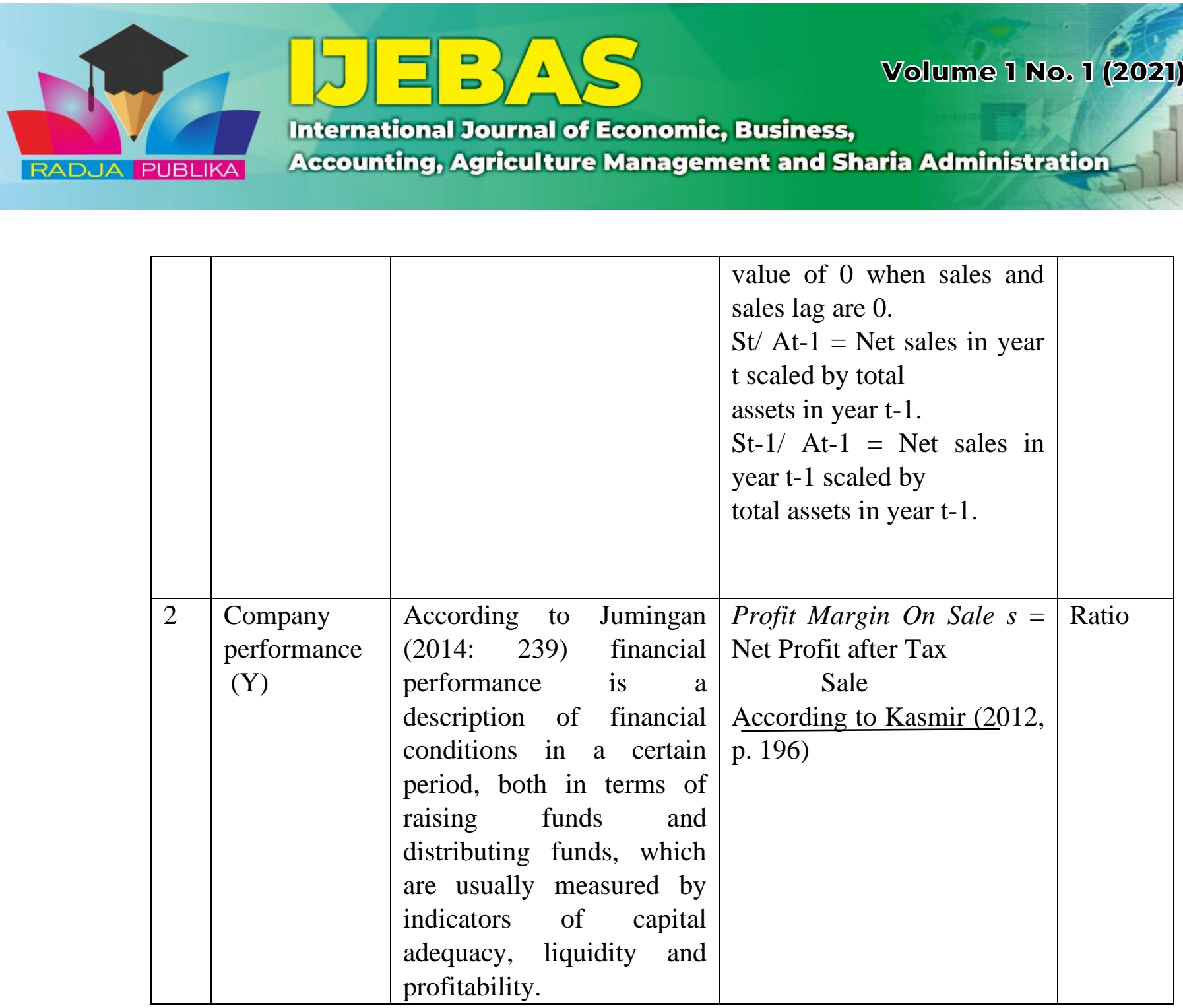

\subsubsection{Data analysis technique}

a) Classic assumption test

\section{1) Normality test}

Normality test is required to perform tests of other variables by assuming that the residual value follows a normal distribution. To test a data is normally distributed or not, it can be known by using a normal plot graph. By looking at the histogram of the residuals. Basis for decision making (Ghozali, 2011:163).

\section{2) Autocorrelation Test}

According to Ghozali (2013) "the autocorrelation test aims to test whether in the linear regression model there is a correlation between the confounding error in period $t$ and the confounding error in period t-1 (previous)". The way that can be done to detect the presence or absence of autocorrelation is to perform the Durbin Watson test.

\section{b) Simple Linear Regression Analysis}

The regression method used in this study is the Simple Linear Regression Method. The simple linear regression method aims to test the effect of two or more independent variables on the dependent variable with a linear equation. The multiple linear method in this study was used to measure promotion and its effect on purchasing decisions. 


\section{c) Determinant Coefficient (R2)}

The value of the determinant coefficient is between zero and one. A small value of $\mathrm{R}^{2}$ means the ability of the dependent variables is very limited. And vice versa if the value is close to 1 , it means that the dependent variables provide almost all the information needed to predict the dependent variables.

\section{d) Hypothesis testing}

\section{1) Coefficient of Determination Test}

$\mathrm{R}^{2}$ is a comparison between the dependent variable $\mathrm{Y}$ which is explained by the variable $\mathrm{X}$ together compared to the total variable $\mathrm{Y}$ there is no definite measure of how much $\mathrm{R}^{2}$ is to state that a variable choice is correct. If $\mathrm{R}^{2}$ is larger and closer to 1 , then the model will be more precise the larger $n$ (sample size) then the value of $R^{2}$ tends to be smaller.

\section{2) Partial Test (t Test)}

according to Sugiyono (2011: 194) $t$ test is used to determine the contribution of each independent variable partially to the dependent variable, using the test of each independent variable regression coefficient whether or not it has a significant effect on the dependent variable

\section{RESULTS AND DISCUSSION}

a. Hypothesis Testing the Effect of Operating Cost Variables (X) on Financial Performance Variables (Y) The form of hypothesis testing based on statistics can be described as follows:

Decision Making Criteria:

1) Reject the hypothesis if tcount $<$ ttable or -tcount $>$ - ttable orvalue Sig. $>0.05$

2) Accept the hypothesis if tcount ttable or -tcount - ttable orSig. $<0.05$

From table 4.9 , the tcount value is 6.862 . With $=5 \%$, ttable $(5 \% ; 36-\mathrm{k} "(1) "=35)$ the ttable value is 2,030 . From the description it can be seen that tcount $(6,862)>$ ttable $(2,030)$, as well as the significance value of $0.000<0.05$, it can be concluded that the first hypothesis is accepted, meaning that Operating Cost variable $(\mathrm{X})$ has a significant effect on the Financial Performance variable (Y). In other words, it means that Operational Costs affect the financial performance of PT. Gotong Royong Jaya. Operating expenses are the main component of calculating operating income, and operating income is an important component of many financial measures. Thus, the lower the company's operating costs, the more profitable a business is in general.

This research is in line with Nuraini Rasyid (2013) Analysis of Operational Costs on Financial Performance at PT. Bank Negara Indonesia (Persero) Tbk Makassar Branch the result is a decrease in the resulting earning power shows the efficient use of capital used for the company's operational costs, based on the results of the analysis, it can be said that the hypothesis proposed by the author can be accepted. Financial performance and financial reports are media used in assessing financial performance so that financial statements are the final result of the accounting process that shows the current condition of the company as a 
communication medium between financial data and company activities for interested parties for decision making in a certain period.

In accordance with the theory according to Nafarin (2010: 76) "Operational costs are the company's main business costs in addition to the cost of goods sold. Operating expenses consist of selling expenses, administrative and general expenses." In carrying out its activities, a company will incur various types of costs including material costs, direct wages and overhead costs where these three costs are called production costs. Other costs for smooth sales or marketing and administrative operational costs.

\section{CONCLUSION}

1. The submission states that: From table 4.7 obtained tcount value of 6.862 With $=5 \%$, ttable $(5 \% ; 36-\mathrm{k}=35)$ obtained ttable value of 2.030 From the description it can be seen that tcount (6.862) > ttable (2.030), and the significance value is $0.00<0.05$ then it can be concluded that the first hypothesis is accepted, meaning Operating costs (X) significant effect on Financial Performance (Y1).

2. From the results of the calculation of the regression analysis that has been carried out, it shows that these variables have a positive and significant influence on financial performance. Therefore, in improving financial performance, it is better to increase the operating costs in the company.

3. Research Limitationsthis only uses the variable Operating Costs, as factors that affect Financial Performance. This variable provides a fairly good contribution. However, it is still very possible that there are other variables that also affect Operational Costs on Financial Performance.

\section{REFERENCE}

Abdullah, M. 2014. Management and Employee Performance Evaluation. : Publisher Aswaja Pressindo. Yogyakarta.

Antoniate, Ihsan. 2011. The Effect of the Use of Flash Learning Media on Student Learning Outcomes in the Sub-Material of Electrolyte and Non-Electrolyte Solutions, Thesis, FMIPA, Unimed, Medan

Anwar Prabu, Mangkunegara. 2011. Human Resource Management. PT. Youth Rosda Karya, Bandung.

Wake up, Wilson. 2012. Human Resource Management. Erlangga. Jakarta

Desseller, Gary. 2015. Human Resource Management (Fourteenth Edition). Salemba Four Jakarta.

Hasibuan, Malay SP 2016. Human Resource Management. Revised Edition. Publisher PT Bumi Aksara Jakarta 
Priest. Ghozali. 2012. Application of Multivariate Analysis with IBM SPSS Program. Diponegoro University, Yogyakarta

Ilham, R. N., Erlina, K. A. F., Silalahi, A. S., \& Saputra, J. (2019). Comparative of the Supply Chain and Block Chains to Increase the Country Revenues via Virtual Tax Transactions and Replacing Future of Money. Int. J Sup. Chain. Mgt Vol, 8(5), 1066.

Irwanto, Andrianus. 2014. Performance of Village Government Organizations in Village Development in Bnuang Ujung Village, Embaloh Hulu District, Kapuas Hulu Regency. Kapuas Hulu Management Science Journal

Moeheriono. 2012. "Competency-Based Performance Measurement".: Raja Grafindo Persada. Jakarta

Rizkia, Milanda W. 2013. Employee Perception Based on Biographical Charateristic on Application of Job Analysis at Linggarjati Baru Jember. Thesis of the Faculty of Economics, University of Jember

Suprapto, Heru. 2011. The Effect of Position Analysis on Performance Achievement of Regional Apparatus Organizations in Kutai Kartanegara. Journal of Economics and Management Kutai Kartanegara

Sutrisno, Edy. 2015. Human Resource Management (seventh issue). Kencana Prenada Media Group Jakarta

ST. Maryam, Rachma Atamimi, Eko Sumartono, Dwi Orbaningsih, Riinawati (2020) GLOBAL FINANCIAL CRISIS MANAGEMENT BY HUMAN RESOURCE MANAGEMENT. Journal of Critical Reviews, 7 (1), 287-290. doi:10.31838/jcr.07.01.53

Syamsiyah, Naili Farida, Rodhiyah. 2013. Analysis of Organizational Performance Measurement Using the Balanced Scorecard Method. Journal of Social and Politic Diponegoro

Tami, Maya A. 2014. The effect of role conflict, financial compensation and non-financial compensation on employee loyalty (study at PT Aston Graphindo Indonesia). Essay. Faculty of Economics and Business, University of Muhammadiyah Surakarta

Tanumihardjo, Shinta et al. 2013. The Effect of Position Analysis on Employee Performance (Study at the Regional Secretariat of Malang Regency). Journal of Public Administration Universitas Brawijaya Malang.

Old, Marihot EH. 2009. Human Resource Management. Grasindo Publisher. Jakarta.

RI Law No.20 of 2003 concerning the National Education System. 
Hero. 2009. Evaluation of Human Resource Performance. Application Theory and Research. Publisher: Salemba Empat. Jakarta

Sandy Martha, Muhammad. 2015. "Work Characteristics and Performance of Extraordinary Lecturers of UIN Sunan Gunung Djati Bandung: Organizational Commitment as a Moderating Variable". Thesis at Widayatama University Bandung

Sugiyono. 2015. Educational Research Methods. Bandung: Alphabeta Publishers

Suliyanto. 2011. "Applied Econometrics: Theory And Application With SPSS". Edition 1. Yogyakarta: ANDI Yogyakarta 